\title{
The preparation and performance of high activity Ni-Cr binary catalysts for direct borohydride fuel cells
}

\author{
YU DanMei*, SHEN Yan, YE Zhen, WEN JiaZhi, WANG Jie \& CHEN ChangGuo \\ College of Chemistry and Chemical Engineering, Chongqing University, Chongqing 400044, China
}

Received December 5, 2012; accepted January 9, 2013; published online March 1, 2013

\begin{abstract}
Ni-Cr binary anode catalysts used in direct borohydride fuel cells (DBFCs) were prepared using a constant potential electrodeposition method. Compared with pure metal Ni catalysts, the electro-oxidation currents of borohydride ions $\left(\mathrm{BH}_{4}^{-}\right) \mathrm{more}$ than doubled when using Ni-Cr binary catalysts under the same conditions. The enhanced activity of the Ni-Cr binary catalysts could be attributed to the change in distribution of $\mathrm{BH}_{4}^{-}$ions on the surface of the $\mathrm{Ni}$ electrode. This is due to $\mathrm{Cr}$ electrodeposits, which allows a greater number of hydrogen atoms to catalyze from each tetrahedron $\mathrm{BH}_{4}^{-}$ion. The performance of Ni-Cr binary catalysts could also be improved by optimizing the electrodeposition conditions. The results show that Ni-Cr binary catalysts are optimally prepared using an electrodeposition method of $1 \mathrm{~s}$ with $\mathrm{Cr}^{3+}$ concentration of $0.2 \mathrm{~mol} \mathrm{~L}^{-1}$ and a potential of $-0.100 \mathrm{~V}$.
\end{abstract}

Ni-Cr binary catalysts, borohydride ion, electro-oxidation, fuel cell

Citation: Yu D M, Shen Y, Ye Z, et al. The preparation and performance of high activity Ni-Cr binary catalysts for direct borohydride fuel cells. Chin Sci Bull, 2013, 58: 2435-2439, doi: 10.1007/s11434-013-5723-4

Direct borohydride fuel cells (DBFCs) have been considered as an attractive energy supply. Particularly for portable applications due to its high theoretical cell voltage $(1.64 \mathrm{~V})$, specific capacity (5.67 $\mathrm{Ah} \mathrm{g}^{-1}$ ), theoretical conversion efficiencies $(91 \%)$, non-toxic catalysts, and the convenient transportation of fuel [1]. These devices employ an alkaline solution of sodium borohydride $\left(\mathrm{NaBH}_{4}\right)$ as fuel and oxygen or hydrogen peroxide as the oxidant. The DBFC converts the chemical energy stored in the borohydride ion $\left(\mathrm{BH}_{4}^{-}\right)$ directly into electricity by redox processes. DBFCs not only overcome the disadvantages of production, storage and transportation issues related to the use of hydrogen gas, but also eliminate safety concerns regarding the use of hydrogen gas as fuel in traditional fuel cells. However, the degree of the direct electro-oxidation reaction of borohydride ions $\left(\mathrm{BH}_{4}^{-}\right)$on the anode can be decreased owing to the hybrid electric potential resulting from the hydrolysis of $\mathrm{BH}_{4}^{-}$ions during DFBC operation [2]. It has been widely reported that the oxidation rate of $\mathrm{BH}_{4}^{-}$is increased by using anode electro-catalysts such as $\mathrm{Ni}, \mathrm{Au}, \mathrm{Pt}$, or Pd despite their lower

*Corresponding author (email: yudanmei-1@163.com) fuel efficiencies [2-5] (e.g. 50\% for Ni [6], 75\% for Pd [7]). Although $\mathrm{Au}$ can catalyze the complete $8 \mathrm{e}^{-}$oxidation of $\mathrm{BH}_{4}^{-}$, its electrochemical activity is relatively low [8]. The hydrolysis and diffusion of $\mathrm{BH}_{4}^{-}$ions through the separation membrane may be suppressed due to the addition of Thiourea (TU) into the alkaline electrolyte during the electrochemical oxidation of $\mathrm{BH}_{4}^{-}$on the $\mathrm{Pt}$ electrode. This addition seems to reduce the operation potential of DBFCs [9].

To take advantage of the various benefits of different catalyst materials and to improve performance, many researchers have been engaged in developing composite anodic materials such as bi-metallic and multi-metallic materials. The activity and stability of bi-metallic catalysts are better than those of mono-metallic catalysts [10]. Considering the high cost of noble metals such as $\mathrm{Au}, \mathrm{Pt}$, and Pd, it is worthwhile to investigate non-precious metal catalysts for use as anode catalysts. Among non-precious metals, nickel is considered a promising candidate for the direct electrooxidation of $\mathrm{BH}_{4}^{-}$. Improved performance of DBFCs has been achieved by using anode loading Ni-based composite catalysts on nickel foams [11]. In this paper, Ni-Cr binary anode catalysts for DBFCs were prepared using a constant 
potential electrodeposition method. This method is considered simple and convenient. The catalytic activity of $\mathrm{Ni}-\mathrm{Cr}$ binary catalysts on the electro-oxidation of $\mathrm{BH}_{4}^{-}$ions was examined. The effects of the electrodeposition conditions on catalyst performance were also investigated.

\section{Experimental}

The preparation of Ni-Cr binary anode catalysts was carried out using a constant potential electrodeposition method with a three-electrode system. A nickel plate $\left(2 \mathrm{~cm}^{2}\right)$ was used as a working electrode, a graphite rod as the counter electrode, and $\mathrm{Ag} / \mathrm{AgCl}$ as the reference electrode. It should be noted that the nickel plate $\left(2 \mathrm{~cm}^{2}\right)$ was polished, cleaned by ultrasonic wave, and washed with distilled water before use as an electrode material. Different Ni-Cr binary catalysts were prepared with different electro-deposition potentials. The concentration of the $\mathrm{Cr}\left(\mathrm{NO}_{3}\right)_{3}$ solution and the deposition time were also varied.

X-ray diffraction (XRD, BDX3200 X-ray diffractometer) was carried out to characterize the component that was electrodeposited onto the surface of $\mathrm{Ni}$ electrode. The catalytic activity of $\mathrm{Ni}-\mathrm{Cr}$ binary catalysts on the electro-oxidation of $\mathrm{BH}_{4}^{-}$ions was investigated using a standard threeelectrode system, with $0.27 \mathrm{~mol} \mathrm{~L}^{-1} \mathrm{NaBH}_{4}$ in $2.0 \mathrm{~mol} \mathrm{~L}^{-1}$ $\mathrm{NaOH}$ electrolyte solution. The nickel plate $\left(2 \mathrm{~cm}^{2}\right)$ was prepared by electrodepositing $\mathrm{Cr}$ as a working electrode. A graphite rod was used as the counter electrode and $\mathrm{Hg} / \mathrm{HgO}$ (MOE, $1 \mathrm{~mol} \mathrm{~L}^{-1} \mathrm{NaOH}$ ) was used as the reference electrode. Cyclic voltammetry tests were carried out by varying the voltage from -1.0 to $-0.4 \mathrm{~V}$ vs. $\mathrm{Hg} / \mathrm{HgO}$ with a scan rate of $10 \mathrm{mV} \mathrm{s}^{-1}$.

Both the constant potential electro-deposition and the cyclic voltammetry $(\mathrm{CV})$ tests were performed with an electrochemical analyzer (CHI660b).

\section{Results and discussion}

Figure 1 summarizes the XRD patterns of pure $\mathrm{Ni}$ and of $\mathrm{Ni}$ with $\mathrm{Cr}$ electrodeposited on surface under various times. Characteristic diffraction peaks of pure $\mathrm{Ni}$ were seen at $44.5^{\circ}, 51.8^{\circ}, 76.4^{\circ}, 92.9^{\circ}$ and $98.4^{\circ}$ (Figure 1(b)). Ni-Cr prepared by electrodepositing over $1 \mathrm{~s}$ also possessed similar XRD patterns but the intensity of the diffraction peaks was significantly reduced (see Figure 1(c)). As the characteristic diffraction peaks of $\mathrm{Cr}$ metal were also not found, it was expected that $\mathrm{Cr}$ could have formed clusters and deposited sporadically on the surface of the Ni electrode [12]. Compared with pure $\mathrm{Ni}$, the intensity of some of the diffraction peaks of the sample prepared by electrodepositing $\mathrm{Cr}$ over $30 \mathrm{~min}$ increased significantly (see Figure 1(d)). This was due to the diffraction peaks (110), (321) and (220) of $\mathrm{Cr}$ overlapping with peaks (111), (220) and (222) of Ni, sug- gesting that the main component of the electrodeposited material was $\mathrm{Cr}$.

$N_{\mathrm{Cr}}$, the number of $\mathrm{Cr}$ atoms electrodeposited onto the $\mathrm{Ni}$ surface, can be calculated by the following formula:

$$
N_{\mathrm{Cr}}=\frac{Q}{z F} \times N_{\mathrm{A}},
$$

where $Q$ is the electric quantity passing through the Ni electrode during the electro-deposition process, $z$ is the number of electrons transferred in the reaction, $F$ is the Faraday constant and $N_{\mathrm{A}}$ is the Avogadro constant. In this case, $z=$ $3, F=96500 \mathrm{C} \mathrm{mol}^{-1}$, and $N_{\mathrm{A}}=6.02 \times 10^{23}$.

Assuming that the $\mathrm{Cr}$ atoms were electrodeposited evenly on the Ni surface one layer at a time, the surface area $(S)$ of the electrode that is covered by $\mathrm{Cr}$ can be given as follows:

$$
S=\pi \times r_{\mathrm{Cr}}^{2} \times N_{\mathrm{Cr}},
$$

where $r_{\mathrm{Cr}}$ represents the radius of the $\mathrm{Cr}$ atom and is equal to $140 \mathrm{pm}$. Characteristic values of the $\mathrm{Ni}$ electrode with electrodeposited $\mathrm{Cr}$ are listed in Table 1. The calculation results show that the area covered by electrodeposited $\mathrm{Cr}$ atoms was $0.05514 \mathrm{~cm}^{2}$, much less than the Ni electrode surface of $2 \mathrm{~cm}^{2}$. This coverage is only $2.75 \%$ of the surface. The $\mathrm{Cr}$ film may not have formed on the Ni surface but could have formed $\mathrm{Cr}$ atom clusters deposited sporadically on the surface. This would have caused the intensity of the XRD diffraction peaks to significantly decrease. However, the atom number and the area covered by $\mathrm{Cr}$ could increase with extended electro-deposition time. For example, the depositing area was found to be $124 \mathrm{~cm}^{2}$ when the electro-deposition time was increased to $1800 \mathrm{~s}$. As the electrode was almost covered with deposited $\mathrm{Cr}$, the diffraction peaks (110), (321) and (220) of Cr appeared in the XRD pattern, which overlapped coincidently with peaks (111), (220) and (222) of Ni metal, leading to increase of diffraction intensity of these peaks.

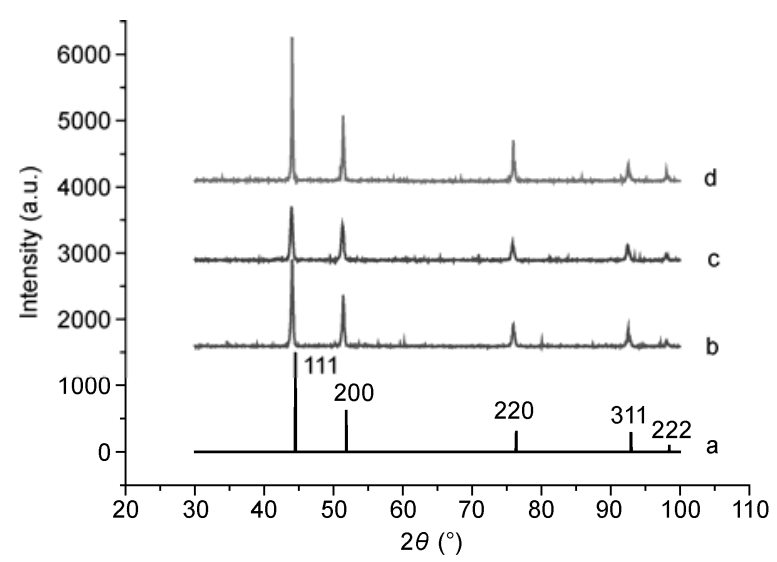

Figure 1 XRD patterns of a standard card of Ni metal (JCPDS No. 04-0850) (a), pure Ni (b), Ni with surface electrodeposited Cr over 1 s (c) and $30 \mathrm{~min}(\mathrm{~d})$. 
Table 1 Characteristic values of Ni electrode surface electrodeposited $\mathrm{Cr}$

\begin{tabular}{cccc}
\hline Electrodepositing time $(\mathrm{s})$ & Electric quantity $(\mathrm{C})$ & $N_{\mathrm{Cr}}$ & Area covered by Cr $\left(\mathrm{cm}^{2}\right)$ \\
\hline 1 & $4.31 \times 10^{-5}$ & $8.96 \times 10^{13}$ & 0.05514 \\
1800 & $9.75 \times 10^{-2}$ & $2.03 \times 10^{17}$ & 124 \\
\hline
\end{tabular}

Figure 2 shows the $\mathrm{CV}$ curves of $\mathrm{BH}_{4}^{-}$using the Ni catalyst. There was an obvious oxidation peak representing $\mathrm{BH}_{4}^{-}$ at approximately $-0.7 \mathrm{~V}$ and at a current of $\sim 6.5 \mathrm{~mA}$ when $\mathrm{Ni}$ was used as a catalyst. This peak was absent from the $\mathrm{CV}$ curve in the $\mathrm{NaOH}$ solution. This indicates that $\mathrm{Ni}$ can catalyze the electro-oxidation of the $\mathrm{BH}_{4}^{-}$ions. Boron atom with a valence electron configuration of $2 \mathrm{~s}^{2} 2 \mathrm{p}^{1}$ is $\mathrm{sp}^{3}$ hybridized and forms a tetrahedral $\mathrm{BH}_{4}^{-}$ion with four hydrogen atoms. Nickel is a group VIIIB element in the fourth row of the periodic table [13], and has a valence electron configuration of $3 \mathrm{~d}^{8} 4 \mathrm{~s}^{2}$. There are three lone pairs of electrons in the $3 \mathrm{~d}$ orbital, so $\mathrm{BH}_{4}^{-}$can be strongly adsorbed onto the Ni surface and form coordinate bonds between the nickel and hydrogen atoms on the $\mathrm{BH}_{4}^{-}$ions. So the electrooxidation reaction of $\mathrm{BH}_{4}^{-}$ion is occurred.

$$
\mathrm{NaBH}_{4}+8 \mathrm{OH}^{-} \rightarrow \mathrm{NaBO}_{2}+6 \mathrm{H}_{2} \mathrm{O}+8 \mathrm{e}^{-}
$$

However, there were more $\mathrm{BH}_{4}^{-}$ions than catalytic activity points and only one hydrogen atom from each $\mathrm{BH}_{4}^{-}$ion tetrahedron could be oxidized (see the inset in Figure 2). This leaves three other hydrogen atoms to be hydrolyzed [14].

$$
\mathrm{NaBH}_{4}+2 \mathrm{H}_{2} \mathrm{O} \rightarrow 4 \mathrm{H}_{2} \uparrow+\mathrm{NaBO}_{2}
$$

Thus, the electro-oxidation of $\mathrm{BH}_{4}^{-}$was reduced and the electrode reaction was hindered by hydrogen gas from hydrolysis.

From Figure 3, it was found that the electro-oxidation of $\mathrm{BH}_{4}^{-}$ions could also be catalyzed by Ni-Cr binary catalysts. With electro-deposition of $1 \mathrm{~s}$, the oxidation current increased by approximately 2.5 times. The enhanced electrooxidation of $\mathrm{BH}_{4}^{-}$ions by the Ni-Cr binary catalysts could

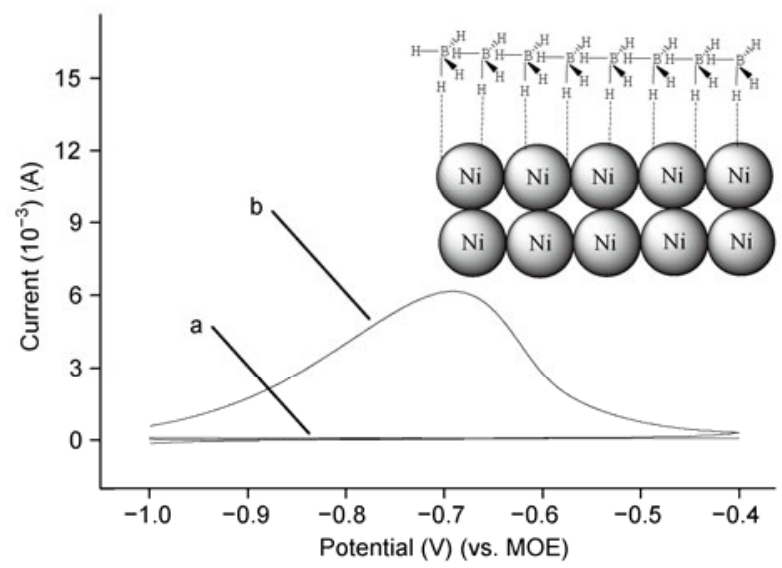

Figure $2 \mathrm{CV}$ curves of $\mathrm{BH}_{4}^{-}$with $\mathrm{Ni}$ catalyst in (a) $2 \mathrm{~mol} \mathrm{~L}^{-1} \mathrm{NaOH}$ solution, (b) $0.27 \mathrm{~mol} \mathrm{~L}^{-1} \mathrm{NaBH}_{4}$ in $2 \mathrm{~mol} \mathrm{~L}^{-1} \mathrm{NaOH}$ solution with a scan rate of $10 \mathrm{mV} \mathrm{s}^{-1}$.

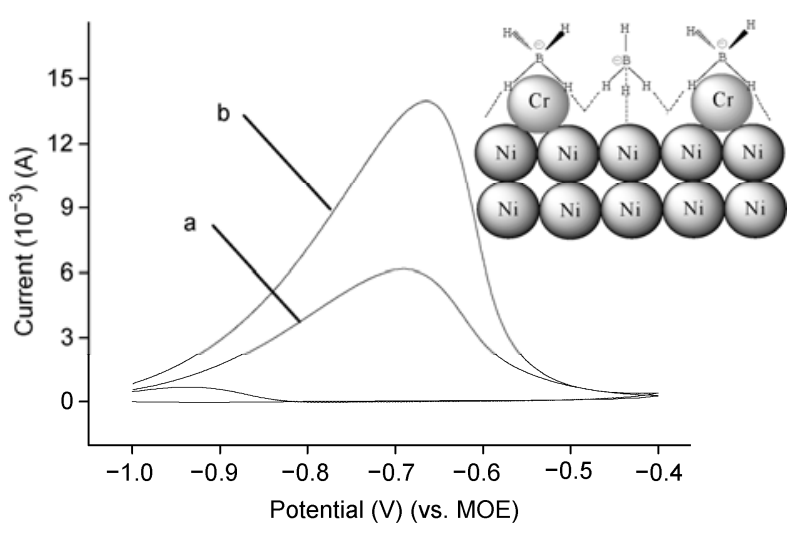

Figure $3 \mathrm{CV}$ curves of $\mathrm{BH}_{4}^{-}$with (a) $\mathrm{Ni}$ and (b) Ni-Cr catalyst in $0.27 \mathrm{~mol}$ $\mathrm{L}^{-1} \mathrm{NaBH}_{4}$ solution with a scan rate of $10 \mathrm{mV} \mathrm{s}^{-1}$.

be attributed to the change in the distribution of $\mathrm{BH}_{4}^{-}$ions on the surface of the electrode from the electrodeposited $\mathrm{Cr}$. As the element $\mathrm{Cr}$ is in the fourth row of the periodic table [13], its valence electron configuration $3 \mathrm{~d}^{5} 4 \mathrm{~s}^{1}$ is in a halffilled stable state, and coordinate bonds between $\mathrm{Cr}$ and $\mathrm{H}$ atoms in the $\mathrm{BH}_{4}^{-}$ion could not form easily. With electrodeposited $\mathrm{Cr}$ on the surface of $\mathrm{Ni}$ electrode, the adsorbance of $\mathrm{BH}_{4}^{-}$ions on the electrode surface decreased significantly, leading to an increase in space between the $\mathrm{BH}_{4}^{-}$ions. Therefore, two or more hydrogen atoms of the tetrahedron $\mathrm{BH}_{4}^{-}$ions could be oxidized, and the catalyst activity was subsequently enhanced significantly (the inset in Figure 3).

Figure 4 displays the $\mathrm{CV}$ curves of $\mathrm{BH}_{4}^{-}$using Ni-Cr catalysts prepared with various electro-deposition times. It can be seen that the electro-oxidation of $\mathrm{BH}_{4}^{-}$ions was enhanced significantly by electrodepositing $\mathrm{Cr}$ on the nickel electrode.

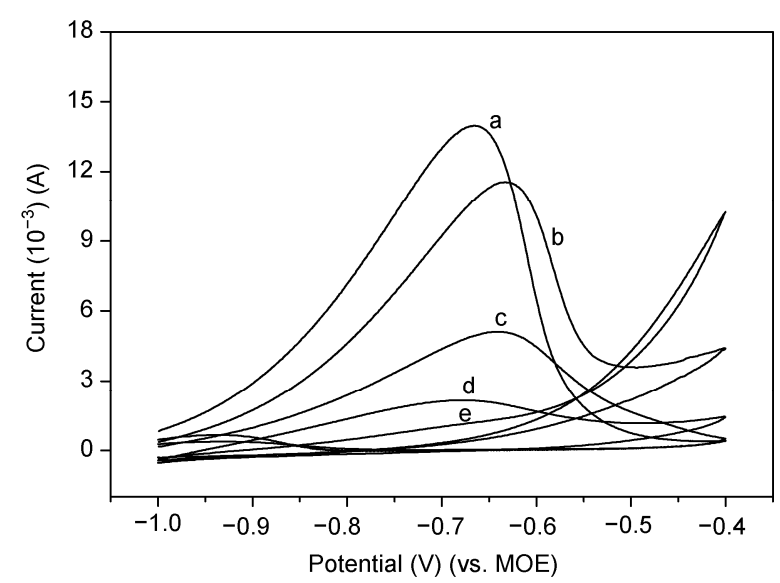

Figure $4 \mathrm{CV}$ curves of $\mathrm{BH}_{4}^{-}$with $\mathrm{Ni}-\mathrm{Cr}$ catalysts prepared in different electrodeposition time. (a) $1 \mathrm{~s}$, (b) $1 \mathrm{~min}$, (c) $10 \mathrm{~min}$, (d) $30 \mathrm{~min}$, (e) $1 \mathrm{~h}$ 
However, this decreased gradually and the oxidation potential slowly shifted to the positive with extended electrodeposition time. With an electro-deposition time of $1 \mathrm{~h}$, the oxidation peak disappeared in the $\mathrm{CV}$ curves of $\mathrm{BH}_{4}^{-}$. This suggests that $\mathrm{Cr}$ could not catalyze on the electro-oxidation of $\mathrm{BH}_{4}^{-}$ions. With electro-deposition times of more than $1 \mathrm{~s}$, the catalytic activity points of $\mathrm{Ni}$ were occupied by more $\mathrm{Cr}$ atoms, resulting in the reduction of the catalytic activity of $\mathrm{Ni}-\mathrm{Cr}$. Therefore, it is suitable to prepare Ni-Cr catalysts with a deposition time of $1 \mathrm{~s}$.

Figure 5 shows the $\mathrm{CV}$ curves of $\mathrm{BH}_{4}^{-}$using Ni-Cr catalysts prepared with different concentrations of $\mathrm{Cr}^{3+}$ while the other conditions of the electro-deposition process were maintained as constants. The electro-oxidation current of $\mathrm{BH}_{4}^{-}$increased with the Ni-Cr catalysts, but decreased gradually with the increase in $\mathrm{Cr}^{3+}$ concentration. As the $\mathrm{Ni}$ catalyst was enhanced by the $\mathrm{Cr}$ deposits, more $\mathrm{Cr}$ atoms occupying the electrode surface resulted in a reduction of the $\mathrm{BH}_{4}^{-}$adsorbance and also reduced the number of catalytic activity points of $\mathrm{Ni}$, decreasing the activity of the Ni-Cr binary catalyst. It should also be noted that the peak potential of $\mathrm{BH}_{4}^{-}$electro-oxidation slowly shifted towards the positive with increased $\mathrm{Cr}^{3+}$ concentration in the electrolyte solution. Some studies have reported $[9,11$, $15,16]$ that the peak potential of $\mathrm{BH}_{4}^{-}$electro-oxidation may vary with different anode catalysts. For example, the peak potential was at approximately -0.40 and $0.20 \mathrm{~V}$ (two continuous oxidation peaks) on $\mathrm{Pt},-0.25 \mathrm{~V}$ on $\mathrm{Au},-0.40 \mathrm{~V}$ on $\mathrm{Cu}$ and $-0.70 \mathrm{~V}$ on $\mathrm{Ni}$ catalyst in alkaline mediums, respec-
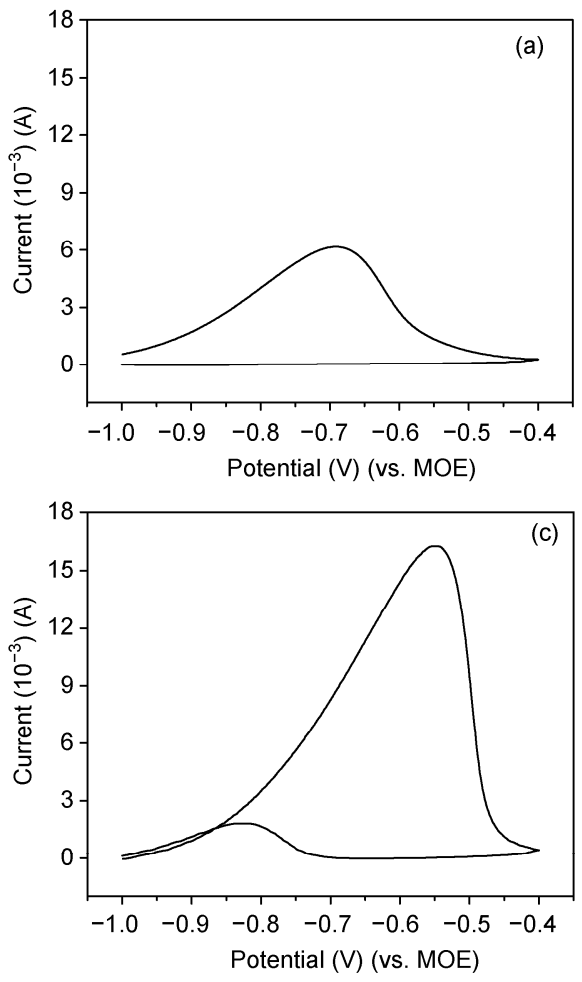

tively.

When using $\mathrm{Ni}-\mathrm{Cr}$ catalysts prepared with different concentrations of $\mathrm{Cr}^{3+}$, the potential of $\mathrm{BH}_{4}^{-}$ion electro-oxidation could shift. However, it has been previously demonstrated [9] that a positive shift of $\mathrm{BH}_{4}^{-}$electro-oxidation potential is not advantageous in increasing the operation potential of DBFCs. The electro-oxidation current of the $\mathrm{BH}_{4}^{-}$ ions were maximized and the positive shift of potential were indistinctive when concentrations of $\mathrm{Cr}^{3+}$ was $0.2 \mathrm{~mol} \mathrm{~L}^{-1}$, suggesting that $0.2 \mathrm{~mol} \mathrm{~L}^{-1}$ was the optimum concentration for $\mathrm{Ni}-\mathrm{Cr}$ catalysts prepared by electro-deposition.

Figure 6(a) presents the $\mathrm{CV}$ curves of $\mathrm{BH}_{4}^{-}$using the $\mathrm{Ni}$ catalyst and Figure 6(b)-(d) shows Ni-Cr catalysts prepared at deposition potentials of $0.100,-0.100$, and $-0.300 \mathrm{~V}$ respectively, while other preparation conditions were maintained as constant. It was found that the electro-oxidation current of $\mathrm{BH}_{4}^{-}$ions using $\mathrm{Ni}-\mathrm{Cr}$ catalysts was considerably increased. The current reached approximately $22 \mathrm{~mA}$ using the catalyst prepared by deposition at $-0.100 \mathrm{~V}$, which was almost 3 times that achieved using pure Ni catalysts. However, the electro-oxidation current decreased slowly with a decrease in deposition potential. As the potential approached $-0.522 \mathrm{~V}$, the content of $\mathrm{Cr}$ in the $\mathrm{Ni}-\mathrm{Cr}$ catalysts was found to increase with the potential shifted to the negative due to easy electro-deposition of $\mathrm{Cr}$ on $\mathrm{Ni}$. This led to a reduction in the number of catalytic activity points on the $\mathrm{Ni}$ surface and a reduced electro-oxidation current of $\mathrm{BH}_{4}^{-}$. The optimum deposition potential found for preparing $\mathrm{Ni}-\mathrm{Cr}$ bimetallic catalysts was $-0.100 \mathrm{~V}$.
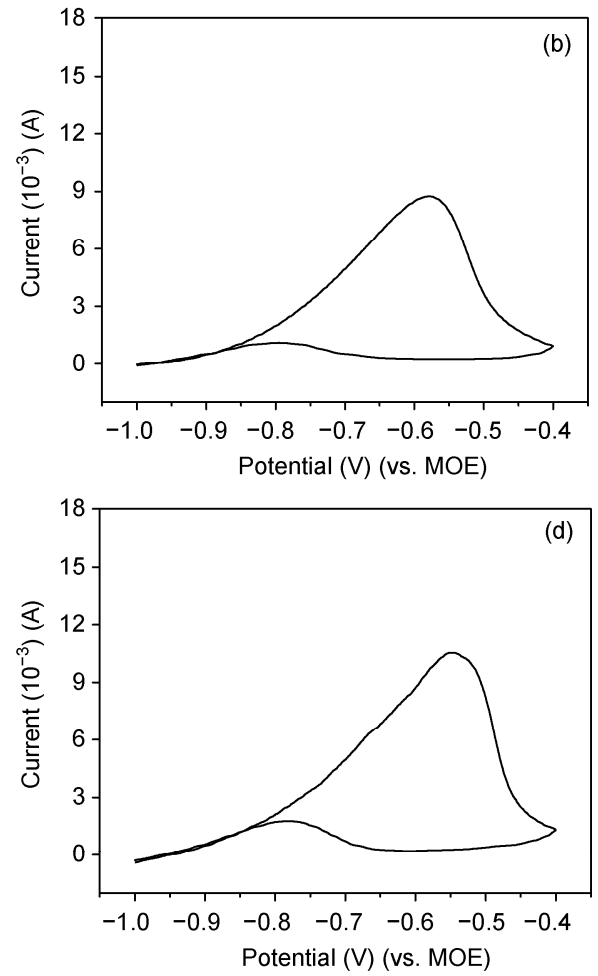

Figure $5 \mathrm{CV}$ curves of $\mathrm{BH}_{4}^{-}$using $\mathrm{Ni}-\mathrm{Cr}$ catalyst prepared with different $\mathrm{Cr}^{3+}$ concentration and a scan rate of $10 \mathrm{mV} \mathrm{s}^{-1}$. (a) $0.0 \mathrm{~mol} \mathrm{~L}^{-1}$, (b) $0.1 \mathrm{~mol} \mathrm{~L}^{-1}$, (c) $0.2 \mathrm{~mol} \mathrm{~L}^{-1}$, (d) $0.3 \mathrm{~mol} \mathrm{~L}^{-1}$. 

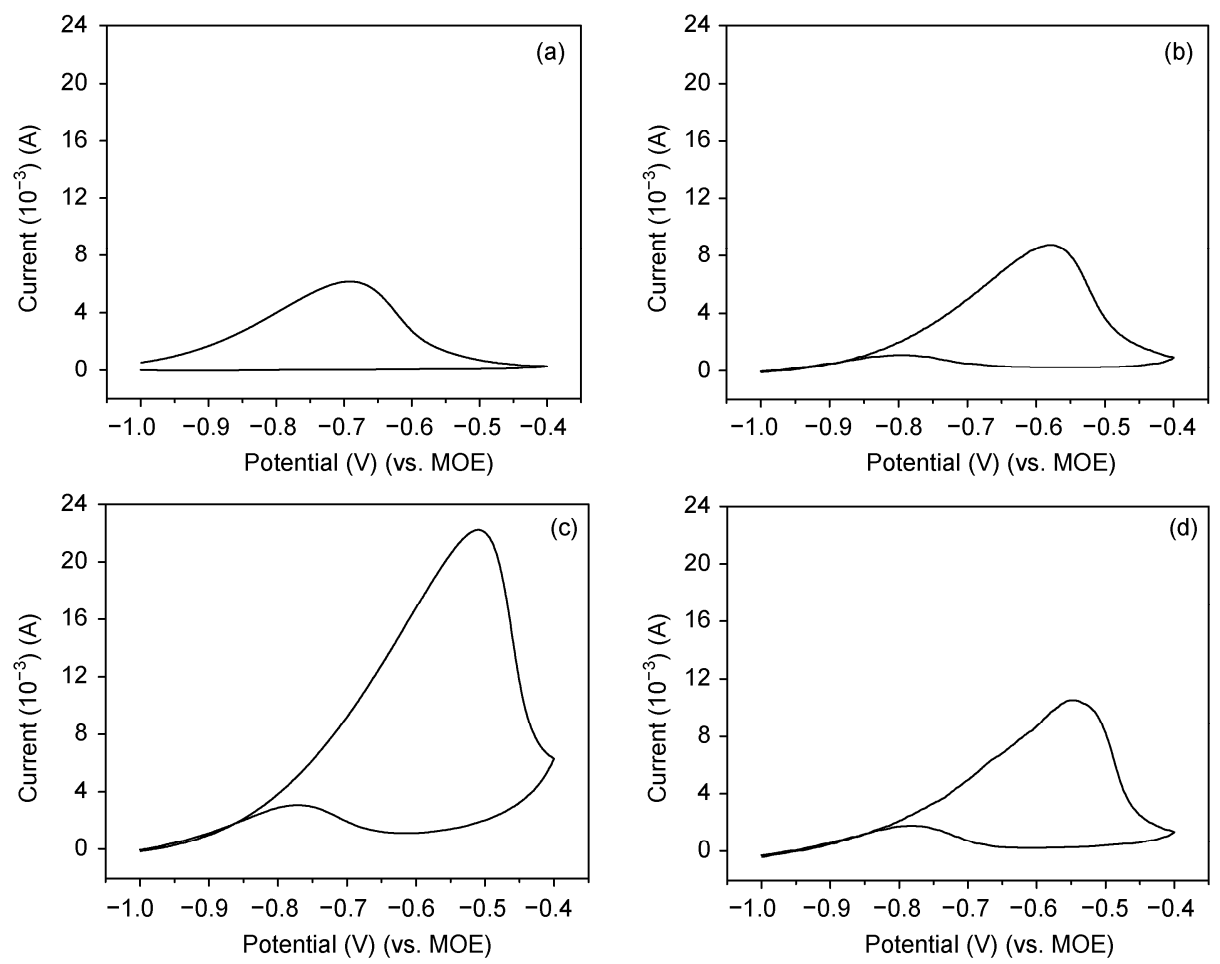

Figure $6 \mathrm{CV}$ curves of $\mathrm{BH}_{4}^{-}$(a) with $\mathrm{Ni}$ catalysts; with $\mathrm{Ni}-\mathrm{Cr}$ catalysts prepared at different electrodeposition potential: (b) $0.100 \mathrm{~V}$, (c) $-0.100 \mathrm{~V}$, (d) $-0.300 \mathrm{~V}$ with a scan rate of $10 \mathrm{mV} \mathrm{s}^{-1}$.

\section{Conclusion}

$\mathrm{Ni}-\mathrm{Cr}$ binary catalysts were prepared by a simple and convenient electro-deposition method. The electro-oxidation performance of $\mathrm{BH}_{4}^{-}$was enhanced significantly using $\mathrm{Ni}-\mathrm{Cr}$ binary catalysts. The improvement of $\mathrm{BH}_{4}^{-}$electrooxidation could be attributed to the increase in the number of hydrogen atoms that each tetrahedron of $\mathrm{BH}_{4}^{-}$ion adsorbed onto the electrode surface, which could then be oxidized directly. The performance of Ni-Cr binary catalysts was also found to be influenced by electro-deposition conditions. The results indicate that optimum conditions for the preparation of $\mathrm{Ni}-\mathrm{Cr}$ binary catalysts using this electrodeposition method were to use a $\mathrm{Cr}^{3+}$ concentration of 0.2 mol $\mathrm{L}^{-1}$, with a depositing potential of $-0.100 \mathrm{~V}$ over $1 \mathrm{~s}$. This work demonstrates an exciting opportunity to effectively improve the catalytic abilities of $\mathrm{Ni}$.

This work was supported by the Graduate Student Science and Technology Innovation Foundation of Chongqing University (CDJXS10220013).

1 Demird U B. Direct borohydride fuel cell: Main issues met by the membrane-eletrodes-assembly and potential solutions. J Power Sources, 2007, 172: 676-687

2 Lei S, Yu D M, Chen C G, et al. Research progress in direct borohyrdride fuel cell (in Chinese). Battery Bimonthly, 2009, 39: 226-228

$3 \mathrm{Li} \mathrm{Z} \mathrm{P,} \mathrm{Liu} \mathrm{B} \mathrm{H,} \mathrm{Arai} \mathrm{K,} \mathrm{et} \mathrm{al.} \mathrm{Development} \mathrm{of} \mathrm{the} \mathrm{direct} \mathrm{borohydride}$ fuel cell. J Alloys Compd, 2005, 404-406: 648-652

4 Indig M E, Snyder R N. Sodium borohydride, an interesting anodic fuel. Electrochem Soc, 1962, 109: 1104-1106

5 Amendola S C, Onnerud P, Kelly M T, et al. A novel high power density borohydride-air cell. J Power Sources, 1999, 84: 130-133

6 Liu B H, Li Z P, Suda S. Anodic oxidation of alkali borohydrides catalyzed by nickel. Electrochem Soc, 2003, 150: A398-A402

7 Liu B H, Li Z P, Suda S. Electrocatalysts for the anodic oxidation of borohydrides. Electrochim Acta, 2004, 49: 3097-3105

8 Liu B H, Li Z P, Suda S. Development of high-performance planar borohydride fuel cell modules for portable applications. J Power Sources, 2008, 175: 226-231

9 Yu D M, Chen C G, Lei S, et al. Enhanced electrochemical oxidation of $\mathrm{BH}_{4}^{-}$on pt electrode in alkaline electrolyte with the addition of thiourea. Adv Mater Res, 2010, 132: 271-278

10 Atwan M H, Macdonald C L B, Northwood D O, et al. Colloidal Au and $\mathrm{Au}$-alloy catalysts for direct borohydride fuel cells: Electrocatalysis and fuel cell performance. J Power Sources, 2006, 158: 36-44

11 Ma J, Sahai Y, Buchheit R G. Direct borohydride fuel cell using Ni-based composite anodes. J Power Sources, 2010, 195: 4709-4713

$12 \mathrm{Li}$ Q, Ma B, Li L, et al. Precise determination of lattice parameters and estimation of the true solubility in $\mathrm{Cu}-\mathrm{Cr}$ alloy (in Chinese). Rare Metal Mat Eng, 2011, 40: 132-134

13 Lide D R. Handbook of Chemistry and Physics. 88th ed. New York: CRC Press, 2008

14 Wang G L, Lan J, Cao D X, et al. Recent advance in research on direct $\mathrm{NaBH}_{4} / \mathrm{H}_{2} \mathrm{O}_{2}$ fuel cells (in Chinese). J Chem Ind Eng, 2008, 59: 805-813

15 Geng X Y, Zhang H M, Ye W, et al. Ni-Pt/C as anode electrocatalyst for a direct borohydride fuel cell. J Power Sources, 2008, 185: 627-632

16 Geng X Y, Zhang H M, Ma Y W, et al. Borohydride electrochemical oxidation on carbon-supported Pt-modified Au nanoparticles. J Power Sources, 2010, 195: 1583-1588

Open Access This article is distributed under the terms of the Creative Commons Attribution License which permits any use, distribution, and reproduction in any medium, provided the original author(s) and source are credited. 